\title{
Software Testing pada Aplikasi Website PT Semen Tonasa menggunakan Metode Assessment Vulnerability
}

\author{
Software Testing on PT Semen Tonasa Website Application using \\ Vulnerability Assessment Method
}

\author{
Reza Maulana $^{1)}$ Indrawan Liwanto $^{2)}$, Christouvel Lucman ${ }^{3)}$
}

'Fakultas sains dan teknologi,prodi sisitem informasi, uin alauddin makassar

${ }^{2,3}$ Sekolah Tinggi Manajemen Informatika \& Komunikasi Kharisma Makassar

2,3J1. Baji Ateka No.20, Makassar, 90134, Telp. 0411-871555 - 871968, Fax. 0411-870098

E-mail: ${ }^{1)}$ saya@rezamaulana.com ${ }^{2)}$ indrawan_14@kharisma.ac.id ${ }^{1},{ }^{3)}$ christouvel_14@kharisma.ac.id

\begin{abstract}
Abstrak - Ancaman terhadap sebuah aplikasi website sangat mungkin terjadi dan sangatlah sulit untuk mengatakan bahwa aplikasi website akan aman dan bebas ancaman atau serangan dari attacker. Sebuah aplikasi website yang terhubung dengan koneksi jaringan komputer akan diakses semua pihak sehingga ancaman selalu ada mengintai. Cara analisa dari aplikasi website yakni dengan mencari kelemahankelemahan yang bisa menjadi pintu masuk seorang attacker. Istilah yang sering digunakan dalam menganalisa kelemahan aplikasi website yaitu analisa vulnerability assessment. Cara melakukan analisa ini yaitu dengan menggunakan teknik String Based Sql Injection. Dengan menggunakan teknik ini attacker dapat menganalisa serta mendapatkan kelemahan-kelemahan yang dimiliki aplikasi website.
\end{abstract}

Kata Kunci: Software Testing, Vulnerability, Website Testing, Security Test

\begin{abstract}
Threats to a website application is likely to occur and it is difficult to say that the application site will be safe and free of threats or attacks from the attacker. A website application that is connected to the computer's network connection will be accessible to all parties so that there is always a lurking threat. How to analysis of a website application that is by looking for weaknesses that could be the entrance to an attacker. The term is often used in analyzing the weaknesses of a website application that analyzes the vulnerability assessment. How to perform this analysis is by using the String Based Sql Injection techniques. By using this technique the attacker can analyze and get weaknesses from website application.
\end{abstract}

Keywords: Software Testing, Vulnerability, Website Testing, Security Test

\section{PENDAHULUAN}

Pengukuran kualitas perangkat lunak sangat diperlukan sebelum sebuah aplikasi akan dirilis atau diluncurkan, hal ini berfungsi untuk menguji maturitas dari sebuah perangkat lunak. Tujuan utama dari pengujian ini adalah untuk meyakinkan kepada pelanggan bahwa sistem tersebut layak untuk digunakan dan memenuhi kinerja persyaratan. Agar perangkat lunak dapat terjamin kualitasnya, maka diperlukan pengendalian,pengujian dan pengelolaan yang mengacu pada kualitas perangkat lunak. Jaminan kualitas perangkat lunak merupakan aktivitas mendasar dalam berbagai bidang perusahaan yang menghasilkan produk yang digunakan oleh pengguna.

Peneliti mengetes aplikasi berbasis website yang dimiliki oleh PT Semen Tonasa berdasarkan Security Test pada web perusahaan yaitu sementonasa.co.id.

\section{METODOLOGI PENELITIAN}

Penelitian dilakukan dengan menggunakan metode Vulnerability. Penelitian dilakukan pada tanggal 13 Juni 2016. 
Registrant Email:atjom@sementonasa.co.id Admin ID:01160472prsd

Billing State/Province:Sulawesi Selatan Billing Postal Code: 9065

Admin Name:Atjo Muchlis

Billing Country:ID

Admin Organization:PT SEMEN TONASA Billing Phone: +081.146685

Admin Street1:Biringere - Pangkep

Admin City:Pangkep

Admin State/Province:Sulawesi Selatan

Billing Email:atjom@sementonasa.co.i

Sponsoring Registrar ID:digitalreg

Sponsoring Registrar Organization:Digital Registra

Sponsoring Registrar Postal Code:5528

Sponsoring Registrar Country:ID

Sponsoring Registrar Phone:0274882257

Name Server:NS1.SEMENTONASA.CO.ID

Name Server:NS2.SEMENTONASA.CO.ID

DNSSEC:Unsigne

Pertama peneliti mengakses situs whois.net kemudian menginput alamat web Semen Tonasa untuk mendapat informasi mengenai alamat tersebut.

sementonasa.co.id is already registered*
Domain ID:PANDI-DO42379
Tech Name:Atjo Muchlis
Domain Name:SEMENTONASA CO.ID
Tech
Organization:PT
Tech Streetl:Biringere - Pangkep
Created On:13-Feb-2004 13:22:59 UTC
Tech City:Pangkep
Last Updated On:30-Sep-2014 00:57:04 UTC
Tech State/Province:Sulawesi Selatan

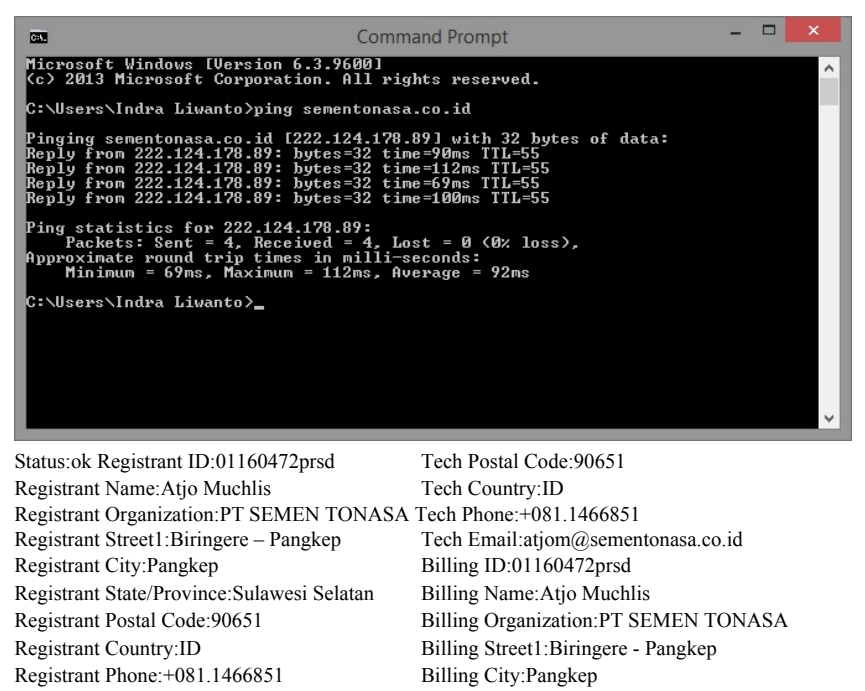

Selanjutnya peneliti mencoba ping ke server sementonasa.co.id untuk mencari tahu apakah ada reply dari server atau tidak dan juga untuk mendapatkan IP server, yang nantinya akan digunakan untuk mencari tahu letak geografis dari $I P$ yang digunakan.
Gambar 1 Hasil Ping ke Server

Gambar 2 Letak Geografis $I P$

Setelah itu peneliti mencoba mengakses beberapa halaman situs sementonasa.co.id untuk mencari string alamat web yang rentan, seperti .php?namavariabel=nilaivariabel.

sementonasa.co.id/berita. php?thn $=2014$

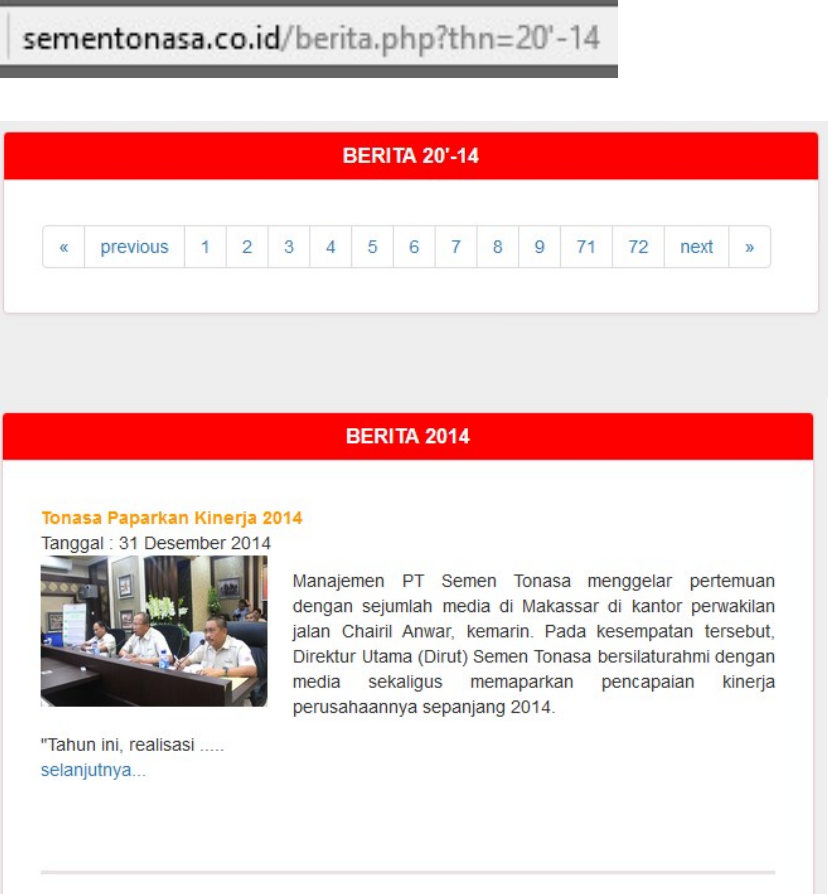

Gambar 3 Alamat dan Tampilan $W e b$

Setelah ditemukan, peneliti menggunakan teknik String Based Sql Injection untuk mencari tahu apakah ada kelemahan pada string alamat tersebut.

Gambar 4 Alamat yang telah diubah dan Hasil 


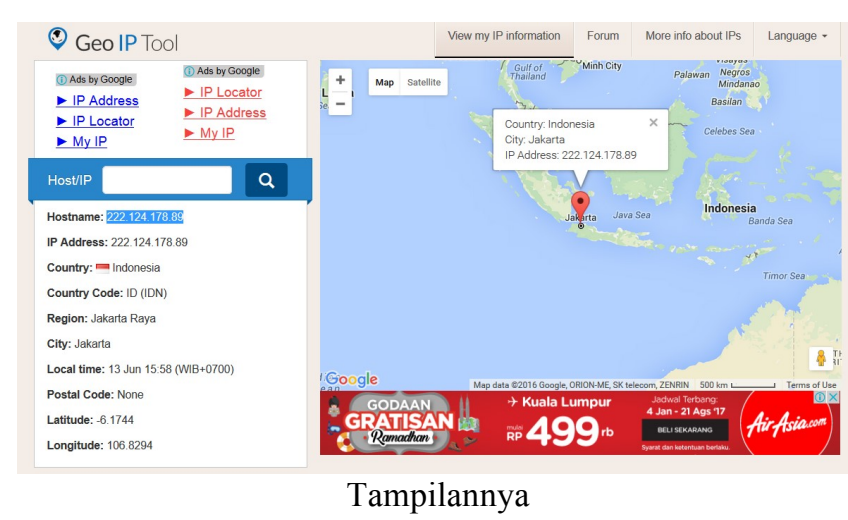

Tampilannya

Dari hasil tersebut dapat diketahui bahwa adanya error pada aplikasi website Semen Tonasa.

\section{HASIL DAN PEMBAHASAN}

Setelah mendapat error tersebut, Peneliti melakukan percobaan lebih lanjut dengan memanfaatkan error yang ada dan kemudian mendapatkan database mysql milik server.

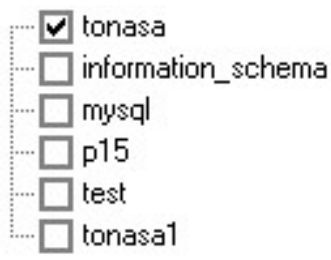

Hasil dari percobaan tersebut menunjukan bahwa tingkat keamanaan pada aplikasi website Semen Tonasa sangat lemah, database dengan mudah dapat diakses.

Hal ini tentu saja dapat berakibat sangat fatal jika data didapatkan oleh pihak yang tidak bertanggungjawab. Data bisa saja dimodifikasi/dihapus atau disisipkan virus yang dapat merusak komputer server.

Sekalipun suatu data hanya bersifat informatif, tetapi jika data tersebut dapat diakses maka dapat disimpulkan aplikasi website tersebut telah gagal dalam hal Security Test.
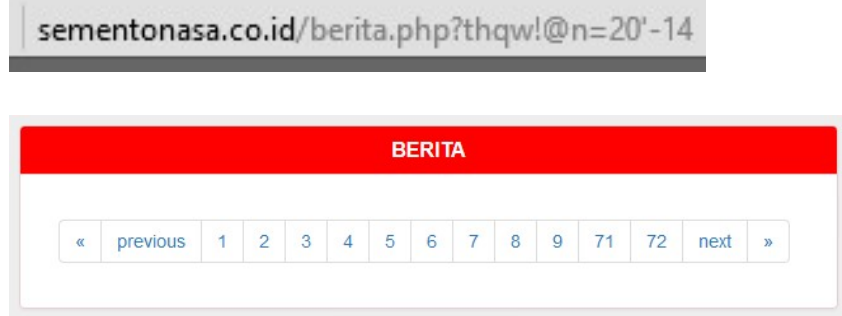

Gambar 5 Alamat yang telah diubah dan Hasil

\section{KESIMPULAN}

Hasil dari penelitian menunjukkan bahwa suatu aplikasi website harus memiliki tingkat keamanan yang tinggi agar data penting website tidak mudah diakses, dimodifikasi, maupun dihapus. Untuk kedepannya diharapkan penelitian ini dapat berguna untuk meningkatkan keamanan pada aplikasi website. Penulis juga berharap semoga penelitian ini dapat berguna bagi pembaca.

\section{UCAPAN TERIMA KASIH}

Penulis mengucapkan terima kasih kepada Reza Maulana, S.Kom., M.T. selaku dosen mata kuliah Software Testing yang telah membimbing dalam kegiatan ilmiah ini. Tak lupa juga Penulis mengucapkan terima kasih kepada teman-teman sekelas yang telah membantu dalam penelitian ini.

\section{DAFTAR PUSTAKA}

Amin, Zaid., (2012), AnalisaVulnerabilitas Host padakeamananjaringan computer di PT. SUMEKS TIVI Palembang (PALTV) Menggunakan Router Berbasis Unix. Jurnal Teknologi dan Informatika (TEKNOMATIKA) Vol 2 No 3 September 2012.

eprints.dinus.ac.id/12051/1/jurnal_11901.pdf
Gupta,Anika, $\quad$ dkk.,(2013),Vulnerability Assessment and Penetration Testing,International Journal of Engineering Trends and Technology-Volume 4 Issue 3- 2013.

Hidayat,Jonny.,(2014).,CEH Certified Ethical Hacker.Jasakom Publishers

S'to.,(2014).,Kali Linux 200\% Attack.Jasakom Publishers 
Zam,Efvy,(2011),Trik Megamankan Website dari Aksi Hacking.Elex Media Komputindo 